\title{
The Effect of Substitution of Fish Meal by Maggot Meal (Hermetia Illucens L) on the Relative Length of Digestive Tract, Histomorphology of Small Intestines and the Percentage of Carcass Parts in Native Chickens
}

\author{
Fuji Astuty Auza ${ }^{1}$, Sri Purwanti ${ }^{2}$, Jasmal A. Syamsu ${ }^{2}$, and Asmuddin Natsir ${ }^{2 *}$ \\ ${ }^{1}$ School of Graduate Studies Hasanuddin University, Makassar, Indonesia \\ ${ }^{2}$ Department of Animal Nutrition, Faculty of Animal Science Hasanuddin University, Makassar (90245), Indonesia \\ *Corresponding author's Email: asmuddin_natsir@unhas.ac.id; (DORCiD: 0000-0001-6442-2788
}

Received: 31 Dec. 2020

Accepted: 13 Feb. 2021

\begin{abstract}
The development of the digestive tract organs is closely related to the increased body weight growth in chickens. The present study aimed to determine the effect of using maggot meal as an antibacterial and protein source of fish meal substitution in diets on the relative length of the digestive tract organs, small intestine histomorphology, and the percentage of the native chicken carcass. A total of 140 one-day-old chickens were randomly assigned to one of the five treatments according to a completely randomized design with four replications for each treatment. The treatments included P0 (basal diet $+15 \%$ fish meal $+0 \%$ maggot meal), P1 (basal diet $+11.25 \%$ fish meal + $3.75 \%$ maggot meal), P2 (basal diet $+7.5 \%$ fish meal $+7.5 \%$ maggot meal), P3 (basal diet $+3.75 \%$ fish meal + $11.25 \%$ maggot meal), and P4 (basal diet $+0 \%$ fish meal $+15 \%$ maggot meal). The results showed that the use of maggot meal in P3 had a significant effect $(\mathrm{P}<0.05)$ on the relative length, villi height, depth of duodenal crypt, jejunum and ileum, villi surface area, the density of jejunum and ileum villi, and percentage of thigh and wing weight. Besides, the treatment tended to increase the relative length of the caecum and colon, surface area of the duodenal villi, and chest weight percentage. However, the treatment did not affect the duodenal villi density and percentage of back weight in native chickens. The use of maggot meal up to $11.25 \%$ in diets can improve the relative length of intestinal, histomorphology of small intestine's villi, and the percentage of carcass parts of native chickens.
\end{abstract}

Keywords: Carcass parts, Digestive tract, Histomorphology, Maggot meal, Native chicken

\section{INTRODUCTION}

The poultry business development has now become an industry with complete components from upstream to downstream, which supports the growth of agribusiness, especially in the livestock sector. In the past, the business was only a side business, and was defined narrowly as a business that produced meat and eggs to fulfill the food needs of families. However, this business is currently developing in a broad sense, namely as the spearhead of improving nutrition, determining the nations' intelligence and health, the strength of national food security, job creation, economic growth, and increasing per capita income. In Indonesia, especially in rural areas, native chickens, has an important role in providing meat and eggs to improve public health. The community raises free-range chickens in their yards using the umbaran system, especially for family savings, which can be sold quickly when they are in need of money.
Meanwhile, in addition to hatching eggs, some are consumed as nutritional sources. Along with the increasing demand for native chickens, meat, and eggs, many local chickens are cultivated semi-intensively and intensively. Domestic chickens are not only taken for meat, but many are also egg-oriented. The obstacle faced in the development of native chickens is the low productivity due to their slow growth. However, domestic chickens have a quite strong disease resistance. One factor influencing chickens' rapid growth is feed efficiency (Willems et al. 2013; Rahmanto 2012). This is due to the digestive process of feed, correlated with the digestive histological conditions. Small intestine is one of the digestive organs that functions in the process of absorption of nutrients. The small intestine is the main organ that plays an essential role in transferring nutrients, and a place for digestion and absorption of digestive products (Suprijatna et al., 2008). Additives function to stimulate growth which can be used in obtaining a good carcass. The additives given are usually based on 
synthetic/chemical antibiotics. However, it is believed that this diet ingredient is not proper for humans to consume. This is due to a residual effect on chicken carcasses, and if the antibiotics are given continuously, it can result in antibiotic resistance for livestock. Consumer desires vary in choosing pieces of the free-range chicken carcass (breast, back, wings, and thighs). These pieces can increase the selling value because, in addition to animal protein sources, the price of the individual pieces are also affordable. One source of natural animal protein that can be used as a feed ingredient is maggot meal, which comes from Black Soldier Fly (BSF) larvae, produced in the second phase of metamorphosis after the egg phase and before the pupal stage, which can play an important role in improving the performance of the digestive tract. According to Jayanegara (2017) maggot meal (Hermetia illucens) has a crude protein content of $44.9 \%$, crude fat of $29.1 \%$, crude fiber of $16.4 \%$, and $8.1 \%$ ash. The nutritional content of maggots, especially crude protein, is quite high, and this shows that maggot (Hermetia illucens) has a considerable potential to be replaced instead of fish meal. Furthermore, the maggot is known to have antibacterial activity in the form of Antimicrobial Peptide (AMP) (Park et al., 2014). As also reported by the research results (Kim and Rhee, 2016), maggot contains high lauric acid, and functions as a natural antibacterial agent. This antibacterial activity dramatically affects the health and development of the digestive tract organs in absorbing nutrients.

With this in mind, the current study aimed to evaluate the effect of using maggot meal (Hermetia illucens) as a source of antibacterial substitution and fish meal protein in diets on the relative length of the digestive tract organs, small intestine's histomorphology, and the percentage of carcass parts in native chickens

\section{MATERIAL AND METHODS}

\section{Ethical approval}

This research was conducted at the Poultry Production Laboratory, Faculty of Animal Science Hasanuddin University Makassar, Indonesia in 2020. This study was approved by the Experimental Animal Ethics Committee of the Faculty of Animal Science, Hasanuddin University Makassar, Indonesia.

\section{Experimental design, native chickens, and feeding}

A total of 140 one-day-old native chickens with an average body weight of $28.74 \pm 1.58 \mathrm{~g}$ were placed in a colony-shaped cage, and each drum contained seven chickens. The trial design used was a completely randomized design with five treatments and four replications for each one, consisting of seven chickens. The treatment diet was formulated as follows; P0: basal diet + $100 \%$ fish meal $(15 \%$ in diet $)+0 \%$ maggot meal $(0 \%$ in diet), P1: basal diet $+75 \%$ fish meal $(11.25 \%$ in diet $)+25 \%$ maggot meal (3.75\% in diets), P2: basal diet $+50 \%$ fish meal $(7.5 \%$ in diets $)+50 \%$ maggot meal $(7.5 \%$ in diets), P3: diets basal $+25 \%$ fish meal $(3.75 \%$ in diets $)+75 \%$ maggot meal (11.25\% in diets), P4: basal diet $+0 \%$ fish meal ( $0 \%$ in diets) $+100 \%$ maggot meal $(15 \%$ in the diet) . The maggot used in this study was maggot that has been dried and grounded into a meal. Maggot that has become meal was mixed with other feed ingredients (Mawaddah and Hermana, 2018) The feed given in the current study was a starter phase in the form of commercial feed for two weeks from the Japfa Confeed Indonesia factory as an adaptation period (Harlystiarini, 2017), then continued with basal feed for the grower and finisher phases. The diets were given from one day to twelve weeks of age every morning and evening according to the requirement of each maintenance phase mentioned by Mawaddah and Hermana (2018), and drinking water was also given ad-libitum. The composition and chemical composition of the diet can be seen in Table 1 .

\section{Preparation and measurement of digestive tract samples and carcass parts}

Intestinal sample preparation was carried out after 90 days of maintenance. Before being slaughtered, chickens fasted for 12 hours, while they were given drinking water. The sample was selected after weighing. The chicken slaughter began with cutting the jugular vein and carotid artery located between the head bone and the first neck segment. Subsequently, the chicken was hung with its legs above, the head was bowed to accelerate the blood-thinning process after the livestock was confirmed to die, then immediately was immersed in the warm water with a temperature of $50-55^{\circ} \mathrm{C}$ for $90-120$ seconds to facilitate the feather removal (Soeparno, 2009). Following that, the offal was removed, the collected samples were part of the digestive tract, and proceed with the separation of the thighs, wings, chest, and back for weighing. Data on the small intestine's length were obtained by separating the digestive tract, namely the small intestine (duodenum, jejunum, and ileum), caecum, and colon, then measured the length of the duodenum, jejunum and ileum, cecum, and colon using a tape measure (Satimah et al., 2019). The small intestine, caecum, and colon organs measured were uncleaned organs. The obtained data were calculated using the following formula of the measurement of the length of the intestinal organs (Incharoen, 2013). 
Relative length of organ : $\frac{\text { length of organ }}{\text { Live weight }} \times 100 \%$

Furthermore, each piece of the carcass was weighed to determine its weight, and compared to carcass weight multiplied by $100 \%$ (Soeparno, 2009).

Percentage of carcass parts : $\frac{\text { Weight of carcass parts }}{\text { Weight of carcass }} \times 100 \%$

Preparation and measurement of small intestine's histomorphology

The histological preparations were performed by making Hematoxylin Eosin (HE) preparations and collaborated with the Maros Veterinary Center. According to Gulo (2013), the histological testing procedure was as follows: For histological tests, small intestine samples were prepared. The samples used were parts of the small intestine consisting of the duodenum, jejunum, and ileum. The duodenum stretched into a parallel loop, starting from the base of the gizzard to the bile ducts' meeting. The jejunum was defined as the small intestine segment between the duodenum and Meckel's diverticulum. Ileum is a segment of the small intestine that ranges from Meckel's diverticulum to the beginning of the caeca branch. The small intestine samples were cut into $2 \mathrm{~cm}$ long pieces for each segment of the small intestine, namely duodenum, jejunum, and ileum, then fixed in $10 \%$ formalin, allowed to soak for 24-48 hours, and then histological preparations were made. To perform the hematoxylin-eosin preparations, a piece of the small intestine segment with a thickness of about $2 \mathrm{~mm}$ was inserted into a tissue basket, then dehydrated. Dehydration action was done by soaking these preparations in succession for 2 hours each in an alcohol solution of $70 \%, 80 \%, 90 \%, 95 \%$, and after that, absorbed in absolute alcohol for 2 hours.

Table 1. Ingredients and chemical analysis of experimental diets.

\begin{tabular}{|c|c|c|c|c|c|}
\hline \multirow{2}{*}{ Feedstuff composition (\%) } & \multicolumn{5}{|c|}{ Treatment } \\
\hline & P0 & P1 & $\mathbf{P 2}$ & P3 & P4 \\
\hline Maize & 64 & 64 & 64 & 64 & 64 \\
\hline Fine rice bran & 12.5 & 12.5 & 12.5 & 12.5 & 12.5 \\
\hline Soybean meal & 1 & 1 & 1 & 1 & 1 \\
\hline Fish meal & 15 & 11.25 & 7.5 & 3.75 & 0 \\
\hline Maggot meal & 0 & 3.75 & 7.5 & 11.25 & 15 \\
\hline Coconut cake meal & 2.5 & 2.5 & 2.5 & 2.5 & 2.5 \\
\hline Vegetable oil & 2 & 2 & 2 & 2 & 2 \\
\hline $\mathrm{CaCO} 3$ & 2 & 2 & 2 & 2 & 2 \\
\hline Premix & 1 & 1 & 1 & 1 & 1 \\
\hline Total & 100 & 100 & 100 & 100 & 100 \\
\hline \multicolumn{6}{|l|}{ Nutrien composition* } \\
\hline Protein $(\%)$ & 18.46 & 18.44 & 18.42 & 18.39 & 18.37 \\
\hline Fat $(\%)$ & 3.31 & 3.79 & 4.27 & 4.75 & 5.24 \\
\hline Crude fiber (\%) & 7.11 & 7.43 & 7.76 & 8.09 & 8.42 \\
\hline $\mathrm{Ca}(\%)$ & 0.99 & 0.97 & 0.96 & 0.94 & 0.93 \\
\hline $\mathrm{P}(\%)$ & 0.91 & 0.81 & 0.71 & 0.6 & 0.5 \\
\hline Ash (\%) & 8.48 & 7.96 & 7.44 & 6.92 & 6.4 \\
\hline BETN (\%) & 61.56 & 59.33 & 59.06 & 58.79 & 58.53 \\
\hline $\mathrm{ME}^{* *}(\mathrm{kkal} / \mathrm{kg})$ & 3063.16 & 3090.54 & 3117.92 & 3145.30 & 3172.68 \\
\hline
\end{tabular}

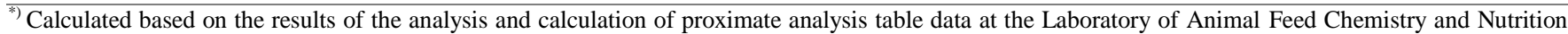
Faculty of Animal Science, Hasanuddin University, Indonesia. P0: Basal ration $+100 \%$ fish meal (15\% in diet) + 0\% Maggot meal (0\% diet), P1: Basal diet + $75 \%$ fish meal (11.25\% in diet) + 25\% Maggot meal (3.75\% in diet), P2: Basal diet $+50 \%$ fish meal (7.5\% in diet) $+50 \%$ Maggot meal (7.5\% in diet), P3: Basal diet $+25 \%$ fish meal (3.75\% in diets) $+75 \%$ Maggot meal $(11.25 \%$ in diet), P4: Basal diet $+0 \%$ fish meal $(0 \%$ in diet $)+100 \%$ Maggot meal (15\% in diet). ${ }^{* *)}$ Metabolic Energy (EM) Value is calculated based on the Balton formula; EM: $40.81 \times(0.87(\mathrm{PK}+(2.25 \mathrm{x}$ LK $)+\mathrm{BETN})+2.5$

Furthermore, according to Zainuddin et al. (2016), the purification process was carried out with xylol for an hour. The tissue was then put into paraffin (in the filtering process), which was in an oven at $60^{\circ} \mathrm{C}$ for one hour. The network was then inserted into a printer whose arrangement was made so that it was filled with liquid paraffin using the paraffin embedding console. Afterward, the preparation was left until the paraffin was hardened enough to cut. Tissue cutting was performed with microtomes at a thickness of 3-4 $\mu \mathrm{m}$. The cut results were attached to the object-glass, then 
were dried and ready to be colored. The staining stage began with deparaffinization and rehydration. The process was carried out by inserting the preparations into a solution of xylol, absolute alcohol, 95\% alcohol, 90\%, 80\%, 70\% alcohol, and water with the time required to insert the preparations into each solution for 2 minutes. After that, the preparations were stained with hematoxylin dye for 10 minutes, then rinsed with running tap water. After that, it was put into eosin for about 20 minutes, then aquadest and dehydrate were added again. In the final stage, the preparation was dripped with adhesive, then covered with a cover glass, and was ready to be viewed using a light microscope with a magnification of 10x. Furthermore, the villi's height, apical width of the villi, width of the basal villi, crypt depth, and villi density were measured. Villi surface area was calculated according to Iji et al. (2001).

Villi surface area: $\frac{(a+b)}{2} \times c$

a: the width of the basal villi; $b$ : the apical width of the villi; c: villi height

\section{Statistical analysis}

Data were analyzed using analysis of variances (ANOVA) according to a completely randomized design. The significant effects of treatments were further determined using Duncan's Multiple Range Test at a 5\% level of significance (Steel and Torrie, 1980).

\section{RESULT AND DISCUSSION}

\section{The relative length of the digestive tract}

Table 2 shows the length of the duodenum of native chickens fed with the substitution of fish meal and maggot meal. The P3 had a longer average value of $3.44 \%$ of the live weight than the treatment without using maggot meal (P0). The variance analysis showed that the use of maggot meal as a substitute for the fish meal had a significant effect on the duodenal length $(\mathrm{P}<0.05)$. A significant increase indicated that the maggot meal can respond to the small intestine's growth, and improve digestive function according to a study conducted by Suprijatna et al. (2008) that the first digestive process occurred in the duodenum. Bile from the liver and enzymes from the pancreas were sent to the duodenum plus the enzymes produced by the intestines digest food to impact the increasing growth. The duodenum's length was closely related to the villi's length and the duodenum's relative weight. The longer the intestinal villi, the optimal surface area for nutrient absorption, and nutrient absorption cause the duodenum to become heavier and more extended. This is in line with the statement of Lenhardt (2001) that the small intestine villi's height was closely related to the potential of the small intestine to absorb nutrients, so that the higher the small intestinal villi, the greater the effectiveness of nutrient absorption through the small intestinal epithelium.

Table 2. The relative length of the digestive tract with substitution of fish meal and maggot meal in native chickens aged 12 weeks.

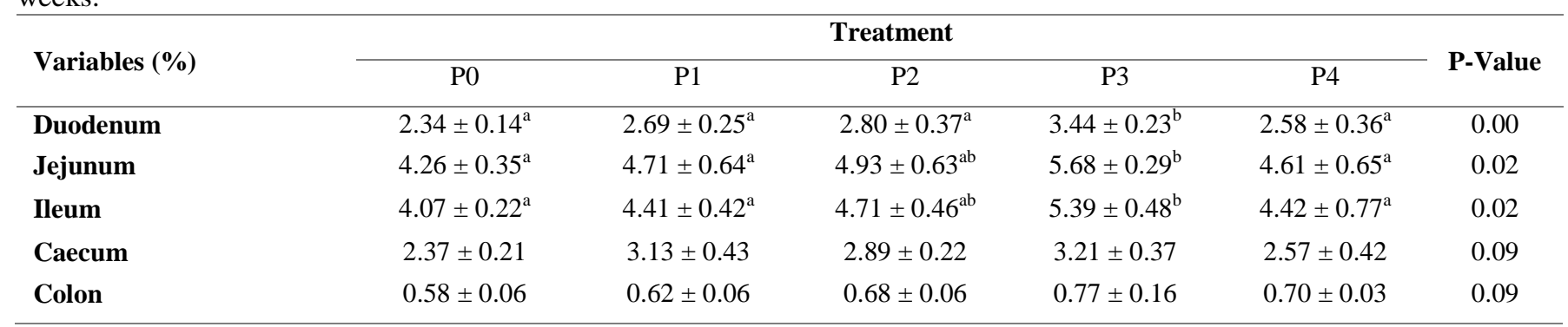

Different superscripts on the same line show significant differences $(\mathrm{P}<0.05)$. P0: Basal diet $+100 \%$ fish meal $(15 \%$ in diet $)+0 \%$ maggot meal $(0 \%$ diet $)$, $\mathrm{P} 1$ : Basal diet $+75 \%$ fish meal (11.25\% in diet $)+25 \%$ maggot meal ( $3.75 \%$ in diet), P2: Basal diet $+50 \%$ fish meal $(7.5 \%$ in diet $)+50 \%$ maggot meal $(7.5 \%$ in diet), P3: Basal diet $+25 \%$ fish meal $(3.75 \%$ in diets $)+75 \%$ maggot meal $(11.25 \%$ in diet $)$, P4: Basal diet $+0 \%$ fish meal $(0 \%$ in diet $)+100 \%$ maggot meal $(15 \%$ in diet $)$

The use of $11.25 \%$ maggot meal (P3) significantly increased the length of the jejunum compared to the control diets $(\mathrm{P} 0)$ and other treatments $(\mathrm{P}<0.05$, Table 2$)$. The increase in the jejunum length corresponded to the increased absorption of nutrients into the intestines' blood. In a study conducted by Bardocz et al. (1995), the increase in the relative length of the jejunum and the intestine's tensile strength can be caused by high levels of complex carbohydrates, including resistant starch oligosaccharides, non-starch polysaccharides, and the percentage of lectins in the diet. The increase in the length of the digestive tract showed the expansion of nutrient absorption and the effectiveness of absorption of food juices. The longer the jejunal organ, the greater the jejunal villi's effect, so that the villi surface area for nutrient absorption was more significant (Nyoman et al., 2018). 
The results of the Duncan region test showed that the use of maggot meal in P3 $3.75 \%$ fish meal $+11.25 \%$ maggot meal) significantly increased ileal length compared to $\mathrm{P} 0, \mathrm{P} 1, \mathrm{P} 2$, and $\mathrm{P} 4$ treatments $(\mathrm{P}<0.05$, Table 2$)$. The average relative length of the ileum ranged $4.07-5.39 \%$. The intake of crude fiber influenced the increase in ileal length. Treatment P3 consumed more crude fiber, followed by P2, P4, P1, and P0. This was supported by Lundin et al. (1993) reporting that fibers can increase the volume density of epithelium and villus in the jejunum, ileum, and duodenum. High crude fiber can stimulate the small intestine's growth, which causes an increase in the small intestine's performance to digest the crude fiber (Savory and Gentle 1976). Providing diets with maggot meals can increase the length of the digestive tract organs, suspected of having an AMP, which functions to inhibit pathogenic microbes from improving intestinal balance benefiting beneficial microorganisms (Harlystiarini, 2017). In addition to AMP, it also contains lauric fatty acid in medium-chain fatty acid, affecting microbes in the small intestine (Spranghers et al., 2017).

The caecum is two bags located on the border between the small intestine and the large intestine. Variance analysis showed that the use of maggot meal does not affect the caecum length. However, P3 treatment $(3.75 \%$ fish meal + $11.25 \%$ maggot meal) of $3.21 \%$ of live weight tended (P: 0.09) to increase the caecum length, compared to other treatments. This is probably due to the use of maggot meal affecting microbial activity on the caecum. This finding was in line with the obtained results of a study conducted by Krismiyanto et al. (2013) revealing that the decreasing population of Escherichia coli (E. coli) can improve the digestion of crude fiber fermented by cellulolytic bacteria caecum, thereby promoting healthy digestion.

The mean relative length of the large intestine or colon was $0.58-0.77 \%$ of the live weight. Based on the analysis of variance, it was indicated that the use of maggot meal can not increase the relative length of the large intestine in the absorption of nutrients but tended (P: 0.09) to increase the length of the colon compared to the control diet (P0, Table 2 ). Low colon activity resulted in a low relative length of the large intestine. This was in line with the study performed by Harlystiarini (2017) revealing that the absorption of crude fiber in the large intestine takes place in small amounts, so it does not affect the increase of colon length of native chickens. There was a close relationship between the increase in colonic length and colonic function in birds. The colon's role is to distribute food waste from the small intestine to the cloaca and where water and some minerals are absorbed. It also functions as a place for fermentation of crude fiber, especially hemicellulose, apart from the caecum in poultry (Gunawan, 2011).

\section{Histomorphology of small intestinal villi}

The measurement of the surface area of the small intestine's villi in native chickens is presented in Table 3 . The variance results showed that the use of maggot meal with fish meal substitution did not affect the duodenal villi's surface area at the age of 12 weeks. However, P3 treatment tended to increase it, compared to other treatments. In contrast, the $\mathrm{P} 3$ treatment had a significant effect $(\mathrm{P}<0.05)$ on the villi of the jejunum and ileum surface area. The largest duodenal villi surface area was found in treatment P3 $\left(50049.48 \mu \mathrm{m}^{2}\right)$ and the smallest in P0 $\left(24128.85 \mu \mathrm{m}^{2}\right)$. The largest surface area of the villi of jejunum and ileum was at P3 (48066.49 $\mu \mathrm{m} 2$ and $\left.43787.35 \mu \mathrm{m}^{2}\right)$, and the smallest in the control (P0) which was $20916.01 \mu \mathrm{m}^{2}$ and 17956.18 $\mu \mathrm{m}^{2}$. In the current study, the surface area of villi in all parts of the small intestine (duodenum, jejunum, and ileum) tended to increase with increasing levels of use of maggot meal (P1, P2, P3, and P4). The duodenal villi surface area's size was relatively larger than the surface area of the villi in the jejunum and ileum. Villi growth is closely related to the development of microbes in the intestine. The use of maggot meal as a substitute for fish meal is thought to have an active compound in the form of an AMP which inhibits the activity of pathogenic microorganisms and is considered to have a relatively better protective effect on maintaining the morphometry of the chickens' villi of the small intestine. This was in line with Harlystiarini (2017) stating that the AMP found in maggots plays an active role in inhibiting pathogenic microbes from improving the gut's balance benefiting beneficial microorganisms.

Villi are small finger-like protrusions found in the small intestine and play an important role in the absorption of nutrients from food in the intestine (Frandson, 1981). Hamdi et al. (2013) stated that the duodenum's intestinal villi are more numerous and longer than the villi in the ileum. The results of the analysis of variance showed a significant effect $(\mathrm{P}<0.05)$ on villi's height in the duodenum of chickens aged 12 weeks (Table 3 ). The mean villi's height in the duodenum ranged from 413.69 to $613.36 \mu \mathrm{m}$. Table 3 shows that the duodenal villi's height at P3 was $613.36 \pm 40.72 \mu \mathrm{m}$ higher than P0, P1, P2, and P4. This indicates that using an $11.25 \%$ maggot meal can trigger the proliferation of intestinal cells during the embryonic period in native chickens to impact cell development to the next phase positively. The difference in the results presented in the table was caused by several factors, including differences in feed consumption and differences in levels of use of maggot meal. However, the villi's height in the small 
intestine represented an area for the complete absorption of nutrients. The transportation of nutrients throughout the body is better and smoother. This was in line with the opinion of Miles et al. (2006) revealing that the increase in villi's height and villi's width is indicated by a wider area of the villi's surface to absorb nutrients into the bloodstream. It was also reported by Ensminger (1992) who claimed that the absorption of nutrients in the small intestine is influenced by the surface area of the small intestine (folds, villi, and microvilli). There was a close relationship between an increase in the number of epithelial cells on the small intestine villi's surface and increased villi's height (Fan et al., 1997).

Table 3. Villi surface area, villi height, villi density and depth of duodenal crypt, jejunum, and ileum treated with fish meal substituted for maggot meal in native chickens aged 12 weeks.

\begin{tabular}{|c|c|c|c|c|c|c|}
\hline \multirow{2}{*}{ Variables } & \multicolumn{5}{|c|}{ Treatment } & \multirow{2}{*}{ p-value } \\
\hline & P0 & $\mathrm{P} 1$ & $\mathrm{P} 2$ & $\mathrm{P} 3$ & $\mathrm{P} 4$ & \\
\hline \multicolumn{7}{|c|}{ Villi surface area $\left(\mu \mathrm{m}^{2}\right)$} \\
\hline Duodenum & $24128.85 \pm 8883.13$ & $35822.88 \pm 9382.55$ & $36198.56 \pm 8572.41$ & $50049.48 \pm 21589.54$ & $26419.29 \pm 7360.65$ & 0.06 \\
\hline Jejunum & $20916.01 \pm 4512.87^{\mathrm{a}}$ & $30521.59 \pm 9278.96^{\mathrm{ab}}$ & $33380.80 \pm 17213.92^{\mathrm{ab}}$ & $48066.49 \pm 15827.33^{\mathrm{b}}$ & $22666.59 \pm 3251.36^{\mathrm{a}}$ & 0.03 \\
\hline Ileum & $17956.18 \pm 4516.05^{\mathrm{a}}$ & $25979.01 \pm 7847.10^{\mathrm{a}}$ & $33175.99 \pm 13434.29^{\mathrm{ab}}$ & $43787.35 \pm 10487.10^{\mathrm{b}}$ & $30131.29 \pm 8518.81^{\mathrm{ab}}$ & 0.02 \\
\hline \multicolumn{7}{|c|}{ Villi height $(\mu \mathrm{m})$} \\
\hline Duodenum & $413.69 \pm 114.28^{\mathrm{a}}$ & $429.03 \pm 53.56^{\mathrm{a}}$ & $464.03 \pm 101.61^{\mathrm{a}}$ & $613.36 \pm 40.72^{\mathrm{b}}$ & $507.49 \pm 29.14^{\mathrm{b}}$ & 0.01 \\
\hline Jejunum & $253.72 \pm 63.07^{\mathrm{a}}$ & $400.26 \pm 38.73^{\mathrm{b}}$ & $432.65 \pm 96.79^{\mathrm{ab}}$ & $457.89 \pm 31.51^{\mathrm{b}}$ & $377.01 \pm 62.60^{\mathrm{b}}$ & 0.00 \\
\hline Ileum & $252.67 \pm 16.26^{\mathrm{a}}$ & $344.39 \pm 43.75^{\mathrm{b}}$ & $406.41 \pm 18.98^{c}$ & $460.59 \pm 17.83^{\mathrm{d}}$ & $307.23 \pm 18.41^{\mathrm{b}}$ & 0.00 \\
\hline \multicolumn{7}{|c|}{ Depth of crypt $(\mu \mathrm{m})$} \\
\hline Duodenum & $209.58 \pm 72.49^{\mathrm{a}}$ & $244.80 \pm 34.85^{\mathrm{a}}$ & $253.16 \pm 39.51^{\mathrm{a}}$ & $361.48 \pm 87.27^{\mathrm{b}}$ & $276.01 \pm 36.06^{\mathrm{b}}$ & 0.02 \\
\hline Jejunum & $210.08 \pm 36.48^{\mathrm{a}}$ & $230.03 \pm 63.36^{\mathrm{a}}$ & $253.89 \pm 26.81^{\mathrm{ab}}$ & $307.76 \pm 52.68^{\mathrm{b}}$ & $280.25 \pm 21.91^{\mathrm{ab}}$ & 0.04 \\
\hline Ileum & $168.58 \pm 46.93^{\mathrm{a}}$ & $191.54 \pm 45.11^{\mathrm{a}}$ & $210.25 \pm 61.62^{\mathrm{ab}}$ & $279.61 \pm 44.27^{\mathrm{b}}$ & $244.48 \pm 30.68^{\mathrm{ab}}$ & 0.03 \\
\hline \multicolumn{7}{|c|}{ Villi density $(\mu \mathrm{m})$} \\
\hline Duodenum & $5500 \pm 1290.99$ & $6250 \pm 957.42$ & $6750 \pm 4787.13$ & $8000 \pm 2449.48$ & $7500 \pm 1732.05$ & 0.68 \\
\hline Jejunum & $6750 \pm 957.42^{\mathrm{a}}$ & $7500 \pm 577.35^{\mathrm{ab}}$ & $8250 \pm 957.42^{\mathrm{bc}}$ & $9000 \pm 816.49^{c}$ & $9500 \pm 1290.991^{c}$ & 0.00 \\
\hline Ileum & $7500 \pm 577.35^{\mathrm{a}}$ & $8250 \pm 500.00^{\mathrm{a}}$ & $9000 \pm 1414.21^{\mathrm{abc}}$ & $10250 \pm 2061.55^{\mathrm{c}}$ & $9500 \pm 577.35^{\mathrm{bc}}$ & 0.04 \\
\hline
\end{tabular}

Different superscripts on the same line show significant differences ( $<<0.05)$. P0: Basal diet $+100 \%$ fish meal (15\% in diet $)+0 \%$ Maggot meal $(0 \%$ diet $)$, P1: Basal diet $+75 \%$ fish meal (11.25\% in diet) $+25 \%$ maggot meal (3.75\% in diet), P2: Basal diet $+50 \%$ fish meal (7.5\% in diet) $+50 \%$ maggot meal (7.5\% in diet), P3: Basal diet $+25 \%$ fish meal (3.75\% in diets) $+75 \%$ maggot meal (11.25\% in diet), P4: Basal diet $+0 \%$ fish meal $(0 \%$ in diet $)+100 \%$ maggot meal $(15 \%$ in diet)

The function of the small intestine villi will be enhanced by the increase in the number of high-size jejunum and ileum villi, which have an important role in the process of absorption of nutrients (Yamauchi and Isshiki, 1991). The variance analysis showed that the use of maggot meal with fish meal substitution had a significant effect $(\mathrm{P}<0.01)$ on the height of the jejunum and ileum's villi. The P3 treatment with the use of maggot meal showed better small intestinal villi's height than the control group. The use of maggot meal (Hermetia illucens L) feed is known to have the potential to increase the surface area of the small intestine villi of the duodenum, jejunum, and ileum. It is suspected that the presence of AMP as an active compound in maggot meal that suppresses pathogenic microorganisms such as $E$. coli and creates ideal conditions for intestinal microecology and benefits beneficial microorganisms, such as Lactobacillus, thereby increasing the performance of the digestive organs. This was reported by Auza et al. (2020) stating that extracts of BSF larvae or maggot have antibacterial activity against Salmonella typhimurium, E. coli Pseudomonas aeruginosa bacteria. The active substance in maggot meal is AMP, which plays an active role in inhibiting pathogenic microbes from improving intestinal balance and benefiting beneficial microorganisms (Harlystiarini, 2017). In addition to AMP, it is suspected that lauric acid acts as a natural antimicrobial (BarrosCordeiro et al., 2014). This condition has an impact on the improvement of mucosal immunity. The decreased number of Gram-negative (pathogenic) bacterial colonies dramatically affects the small intestinal villi's height. Likewise, if the pathogenic bacteria increases, it can inhibit the growth of small intestinal villi's height. Fuller (1992) in his research revealed that the balance of the intestinal microflora would occur in case the beneficial microbes 
could suppress the harmful microbes by pushing out the pathogenic microbes. The higher the number of nonpathogenic bacterial colonies, the better the performance in suppressing pathogenic bacteria. One way to obtain a high proportion of non-pathogenic bacteria or lactic acid bacteria is to use several protein peptides, such as antimicrobial peptides and support beneficial bacteria, such as lactic acid bacteria (LAB); these bacteria can dominate the population. Animal health is influenced by the number of microbes in the microflora (Philip, 1993).

The use of maggot meal showed a significant effect on the depth of crypt in the duodenum, jejunum, and ileum of native chickens at 12 weeks of age $(\mathrm{P}<0.05$, Table 3$)$. The depth of crypt in treatment P3 and P4 was better than P2, $\mathrm{P} 1$, and P0. The highest value for the depth of crypt in treatment P3 was $361.48 \mu \mathrm{m}$, and the lowest was at P0 of $209.58 \mu \mathrm{m}$. This was because the level of using maggot meal to substitute fish meal impacts the growth of cells in the small intestine of the duodenum, jejunum, and ileum. There are also suspected antimicrobial peptides and lauric acid in maggot meal, which play an active role in inhibiting pathogenic bacteria such as E. coli. This was in agreement with the research by Harlystiarini (2017) who states that BSF larvae extract inhibitory activity against E. coli and Salmonella $s p$.

The AMP in the treated feed would positively affect the balance and microecological conditions of the gut that inhibit pathogenic microorganisms, such as Coliform, and benefit non-pathogenic microorganisms, including Lactobacillus (Wang et al., 2006; Tang et al., 2009). This condition triggered the increase in the value of the crypt's depth, and the villi's height can affect improving digestive ability. The higher the size of the villi and the depth of the crypt, the wider the area of absorption of nutrients by the small intestinal wall to stimulate the growth (Rahmawati, 2016). Based on the morphology and function, nutritional requirements in the early growth period depend on the digestive tract (Zhou et al., 2013). The histological growth of the small intestine can assist the chickens in digesting the feed earlier. At the beginning of hatching, the chickens still have the remaining yolk sac, which is absorbed into the intestines as nutrients before getting reliable feed. The fast growth of the digestive tract organs can adjust and adapt quickly to the previously given feed.

\section{Percentage of carcass parts}

The results of measurements of small intestinal villi density in native chickens are presented in Table 3. The results of the current study showed no difference in villous density in the duodenum, but it had a significant effect on the jejunum and ileum $(\mathrm{P}<0.05)$. The greatest duodenal villi density at 12 weeks was P3 $(8000 \mu \mathrm{m})$, and the smallest was P0 $(5500 \mu \mathrm{m})$. The greatest villous density in the jejunum was at P4 $(9500 \mu \mathrm{m})$, and the smallest at P0 (6750 $\mu \mathrm{m})$. Meanwhile, the largest villi density was in the ileum, namely at P3 $(10250 \mu \mathrm{m})$, and the smallest at P0 $(7500 \mu \mathrm{m})$. Table 3 shows the density of villi (number of villi / $1 \mu \mathrm{m}$ ) is the smallest in the duodenum and the largest in the ileum. The effectiveness of using maggot meal (P3 and P4) on villous density was seen in the jejunum and ileum. This indicated that the possibility of AMP and high lauric acid in maggot meal inhibit pathogenic microbes and benefit beneficial microorganisms, such as LAB, so that LAB colonized the jejunum and ileum which can affect villi development. As stated by Harlystiarini (2017) and BarrosCordeiro et al. (2014), the active substances contained in maggot meal are AMP and lauric acid, which play an active role in inhibiting pathogenic microbes, so that they can improve balance and benefit from the intestine. According to Ferrer et al. (2019), the density and size of villi in the small intestine can explain the rate of change in absorption in the villi surface area. This indicated a correlation with the absorption capacity of poultry (Ebadias, 2011). The small intestine of livestock with heavier body weight is characterized by a more extended absorption area of the small intestine and a wider absorption area than the small intestine of birds with lighter bodyweight (Yamauchi and Isshiki,1991).

Table 4. Average percentage of carcass parts weight of village chickens aged 12 weeks.

\begin{tabular}{|c|c|c|c|c|c|c|}
\hline \multirow{2}{*}{ Variables } & \multicolumn{5}{|c|}{ Treatment } & \multirow{2}{*}{ P-Value } \\
\hline & P0 & P1 & $\mathbf{P 2}$ & P3 & $\mathbf{P 4}$ & \\
\hline Chest (\%) & $16.20 \pm 2.83$ & $19.26 \pm 4.75$ & $19.38 \pm 2.90$ & $23.54 \pm 1.82$ & $21.82 \pm 4.17$ & 0.07 \\
\hline Back $(\%)$ & $16.47 \pm 3.07$ & $17.28 \pm 1.91$ & $18.93 \pm 7.59$ & $23.72 \pm 3.45$ & $23.62 \pm 4.58$ & 0.10 \\
\hline Thighs (\%) & $22.70 \pm 3.65^{\mathrm{a}}$ & $25.51 \pm 2.84^{\mathrm{a}}$ & $26.61 \pm 2.56^{\mathrm{a}}$ & $36.49 \pm 3.63^{b}$ & $34.95 \pm 5.93^{\mathrm{b}}$ & 0.001 \\
\hline Wings (\%) & $11.00 \pm 1.13^{\mathrm{a}}$ & $10.97 \pm 1.18^{\mathrm{a}}$ & $13.72 \pm 1.30^{\mathrm{b}}$ & $15.58 \pm 0.57 \mathrm{c}$ & $11.94 \pm 0.91^{\mathrm{a}}$ & 0.001 \\
\hline
\end{tabular}

Different superscripts on the same line show significant differences $(\mathrm{P}<0.05)$. P0: Basal diet $+100 \%$ fish meal $(15 \%$ in diet $)+0 \%$ Maggot meal (0\% diet), P1: Basal diet $+75 \%$ fish meal (11.25\% in diet $)+25 \%$ maggot meal (3.75\% in diet), P2: Basal diet $+50 \%$ fish meal (7.5\% in diet $)+50 \%$ maggot meal $(7.5 \%$ in diet $)$, P3: Basal diet $+25 \%$ fish meal (3.75\% in diets) $+75 \%$ maggot meal (11.25\% in diet), P4: Basal diet $+0 \%$ fish meal $(0 \%$ in diet $)+100 \%$ maggot meal $(15 \%$ in diet $)$ 
The results of the present study revealed that the use of maggot meal did not affect the percentage of chest weight. However, it tended to $(P=0.07)$ increase the percentage of breast weight in treatment $\mathrm{P} 3$. Based on Table 4, it can be seen that the P3 treatment (3.75\% fish meal $+11.25 \%$ maggot meal) had the highest average percentage value of breast weight, namely $23.54 \%$, while the lowest average percentage of breasts was in the control treatment ( $15 \%$ fish meal $+0 \%$ maggot meal) which was $16.20 \%$. This shows that using $11.25 \%$ maggot meal in the diet can increase the percentage of breasts in native chickens. The increase in the percentage of breasts at the level of $11.25 \%$ using maggot meal was most likely due to AMP, which can improve the digestive tract, thereby contributing to the growth of body weight and carcass. This is reinforced by Harlystiarini (2017) stating that AMP in feed can improve intestinal balance and create intestinal microecological conditions that suppress pathogenic bacteria. Besides, maggot meal is known to have a high enough fat content. The high and low percentage of the carcass is believed to be related to the high and low-fat content in the diet leading to an increase in the digestibility of feed in the intestine which is correlated with an increase in the carcass, including the percentage of native chickens' breast. In addition, maggot flour is known to have a high enough fat content. The high and low percentage of the carcass was related to the high and lowfat content in the diet, which allows an increase in the carcass, including the percentage of native chickens' breast. Whereas in $\mathrm{P} 4$ treatment, there was a decrease in the percentage of breasts with the use of $15 \%$ maggot meal in the diet, presumably due to the presence of crude fiber and chitin compounds which were high enough to inhibit the chickens' digestion leading to slow growth, and consequently decreases the percentage of carcass weight. As reported by Purnamawati (2015), the high content of chitin will make the diet to be amba (voluminous), thus reducing the consumption of chicken feed. This shows that maggot meal can work optimally up to a usability level of $11.25 \%$ in spurring the growth of carcass weight, including the percentage of native chickens' breasts.

The results of Duncan's multiple area test showed that the use of maggot meal substituted instead of fish meal did not significantly affect the percentage of back weight, but tended to increase the percentage of back weight. Table 4 shows that the highest percentage value of back weight was found in the P3 treatment $(23.72 \%)$ and the lowest was in the control at $16.47 \%$. This was probably because the mineral content in each diet treatment was not much different so that some components were composed of more bones, such as back and wings. The back is dominated by bones so that not too much muscle is formed. The results of the present study were not much different from those reported by Marfuah (2016) revealing that the percentage of backs of 6 weeks old broiler chickens ranged $21.36-22.31 \%$ of the carcass weight. It was also reported in the study by Merkley et al. (1980) that feed is one factor affecting the percentage of carcass pieces in poultry consisting of the breast, back, thighs, and wings.

The thigh's carcass is the part that grows earlier than the other parts (Swatland, 1984). The results of the current study showed that the use of maggot meal had a significant effect on the percentage of thigh weight $(\mathrm{P}<0.05)$. The average percentage of thigh weight was 22.70-36.49\%. Table 4 shows that the P3 treatment has a high carcass percentage value than the control and other treatments. The increase in the percentage of thigh weight in P3 (3.85\% fish meal $+11.25 \%$ maggot meal) is thought that maggot meal with a high enough protein and fat content can increase the availability and digestibility of feed nutrients in the digestive tract of chickens so that it will result in an increase in carcass including the chickens' thighs. As stated by, oil or lipids have an important role in the growth of chickens (Fadilah et al., 2007). In this case, it functioned as an energy source, helping the absorption of fat-soluble vitamins, reducing dustiness in feed, and may also help palatability of food, as well as serving as a source of heat. Meanwhile, protein plays an essential role in the growth of muscle meat, so that a ratio with a high protein content will result in a high percentage of thigh weight. According to Fahmi (2015), the protein content from maggots or BSF larvae was $44.26 \%$.

The results of the analysis of variance showed that the use of maggot meal had a significant effect $(P<0.05)$ on the percentage of wing weight. The current study indicated that the mean wing weight percentage varied from 11.00 to $15.58 \%$ (Table 4). The highest percentage value of back weight was found in the P3 treatment, which was $15.68 \%$, and the lowest was in the control at $11 \%$. The results were lower than those reported by Suartiningsih et al. (2017), which amounted to 16.8$17.86 \%$ in native chickens. The increase in the percentage of wing weight was probably due to the high mineral content of calcium and phosphorus in maggot meal, and not much different from fish meal. The results of this study were in line with Pesik et al. (2016) claiming that the maggot meal (Hermetia illucens) used in this study is 
thought to have calcium (Ca), which has a better biological value than calcium $(\mathrm{Ca})$ in fish meal. According to Nita et al. (2015), food substances in the form of protein and energy, and minerals are used to form bones, meat, and feathers based on the size and structure of wing feathers.

\section{CONCLUSION}

The use of maggot meal on P3 (3.75\% fish meal $+11.25 \%$ maggot meal) had a significant effect $(\mathrm{P}<0.05)$ on relative length, villi height, depth of duodenal crypt, jejunum and ileum, villi surface area, the density of jejunum and ileum villi and percentage of thigh and wing weight. Besides, the treatment tended to increase the relative length of the caecum and colon, surface area of the duodenal villi, and chest weight percentage. However, the treatment did not affect the duodenal villi density and percentage of back weight in native chickens. The use of maggot meal up to $11.25 \%$ in diets can improve the relative length of the digestive tract organs, a histomorphological feature of the small intestine villi, and the percentage of carcass parts in native chickens

\section{DECLARATIONS}

\section{Acknowledgments}

The authors would like to express their sincere thanks to the Ministry of Education and Culture for providing Beasiswa Pendidikan Pascasarjana Dalam Negeri scholarship for the current study and the Laboratory of Poultry Production Hasanuddin University and Center for Veterinary Medicine Maros. They provided laboratory equipment and research facilities during the experiment.

\section{Competing interests}

The authors did not have any conflict of interest.

\section{Author's contributions}

Fuji Astuty Auza designed, conducted the experiment, collected and analyzed samples in the laboratory, obtained data, drafted the paper, read and approved the final draft of the manuscript. Sri Purwanti and Jasmal A. Syamsu designed and directed the experiment, including laboratory analysis, data analysis, writing, read and approved the final draft of the manuscript. Asmuddin Natsir was responsible for the whole experiment, including designing, directing, monitoring, data analysis, writing, read and approved the final draft of the manuscript.

\section{REFERENCES}

Auza FA, Purwanti S, and Syamsu JA, and Natsir A (2020). Antibacterial Activities of Black Soldier Flies ( Hermetia Illucens . L) Extract towards the Growth of Salmonella typhimurium, E . coli and Pseudomonas aeruginosa. IOP Conf. Series: Earth and Environmental Science, $\quad 492(1)$ : $1-6$ DOI: http://www.doi.org/10.1088/1755-1315/492/1/012024

Bardocz S, Grant G, Ewen SWB, Duguid TJ, Brown DS, Englyst K, and Pusztai A (1995). Reversible effect of phytohaemagglutinin on the growth and metabolism of rat gastrointestinal tract. BMJ Journal, 37(3): 353-360. DOI: http://www.doi.org/10.1136/gut.37.3.353

Barros-Cordeiro KB, Báo SN, and Pujol-Luz JR (2014). Intra-puparial development of the black soldier-fly, Hermetia illucens. Journal of insect science (Online), 14(83): 1-10. DOI: http://www.doi.org/10.1673/031.014.83

Ebadias G (2011). Effects of supplemental glutamine and glutamate on growth performance, gastrointestinal development, jejunum morphology and clostridium perfringens count in caecum of broilers effects of supplemental gastr. Swedish University of Agricultural, pp. 14-19. Available at: http://stud.epsilon.slu.se/2136/

Ensminger ME (1992). Animal Science. (Animal Agriculture series). 3rd edition. Interstate Publisher, Inc. Danville Illinois, pp. 820-850. Available at: https://www.abebooks.com/book-search/kw/animalscience-animal-agriculture-series-m-e-ensminger

Fadilah R, Polana A, Alam S, and dan Parwanto E (2007). Sukses beternak ayam broiler. Agromedia Pustaka, Jakarta, pp. 65-87. Available at: https://agromedia.net/katalog/sukses-beternak-ayambroiler/

Fahmi MR (2015). Optimalisasi proses biokonversi dengan menggunakan mini-larva Hermetia illucens untuk memenuhi kebutuhan pakan ikan. Prosiding seminar nasional masyarakat biodiversity indonesia, 1(1): 139-144. DOI: http://www.doi.org/10.13057/psnmbi/m010124

Fan YK, Croom J, Christensen VL, Black BL, Bird AR, Daniel LR, Mcbride BW, and Eisen EJ (1997). Jejunal glucose uptake and oxygen consumption in Turkey poults selected for rapid growth. Poultry Science, 76(12): 1738-1745. DOI: http://www.doi.org/10.1093/ps/76.12.1738

Ferrer R, Planas JM, and Moreto M (2019). Cell apical surface area in enterocytes from chicken small and large intestine during development. Journal of Chemical Information and Modeling, 53(9): 1689-1699. DOI: http://www.doi.org/10.3382/ps.0741995

Frandson RI (1981). Animal anatomy and physiology. 3rd Edition. Philadelphia: Lea and Febiger, pp. 553. Available at: https://www.amazon.com/Anatomy-Physiology-Animals-packedillustrations/dp/B01MA3OJBY

Fuller R (1992). Probiotics, the Scientific Basis. Chapman \& Hall, London, pp. 1-8. DOI: http://dx.doi.org/10.1007/978-94-011-23648

Gulo FDK (2013). Gambaran histologis proventrikulus, duodenum, dan hati ayam broiler yang diberi ekstrak plus. Thesis. Kedokteran Hewan. IPB University Scientific Repository, pp. 26-41. Available at: http://repository.ipb.ac.id/handle/123456789/66742

Gunawan Y (2011).Organ dalam ayam kampung umur 10 minggu yang diberi ransum mengandung bungkil biji jarak pagar (Jatropha Curcas L) terfermentasi rhizopus oligosporus. Thesis. Nutrisi dan Teknologi Pakan. IPB University Scientific Repository, pp. 29-40. Available at: http://repository.ipb.ac.id/handle/123456789/51156

Hamdi H, El-Ghareeb AW, Zaher M, and Amod A (2013). Anatomical, 
histological and histochemical adaptations of the avian alimentary canal to their food habits: II- Elanus Caeruleus. International Journal of Scientific and Engineering Research, 4(10): 1355-1363. Available at: http://www/ijser.org/

Harlystiarini (2017). Pemanfaatan tepung larva black soldier fly (Hermetia Illucens) sebagai sumber protein pengganti tepung ikan pada ransum puyuh petelur (Cortunix Cortunix Japonica). Thesis. Nutrisi dan Teknologi Pakan. IPB, pp. 26-43. Available at: http://repository.ipb.ac.id/handle/123456789/91091

Iji PA, Hughes RJ, Choct M, and Tivey DR (2001). Intestinal structure and function of broiler chickens on wheat-based diets supplemented with a microbial enzyme. Asian-Australasian Journal of Animal Sciences, $\quad 14(1)$ : $\quad 54-60 . \quad$ DOI: http://www.doi.org/10.5713/ajas.2001.54

Incharoen T (2013). Histological adaptations of the gastrointestinal tract of broilers fed diets containing insoluble fiber from rice hull meal. American Journal of Animal and Veterinary Sciences, 8(2): 79-88. DOI: http://www.doi.org/10.3844/ajavssp.2013.79.88.

Jayanegara A, Yantina N, Novandri B, Laconi EB, Nahrowi N, and Ridla M (2017). Evaluation of some insects as potential feed ingredients for ruminants: Chemical composition, in vitro rumen fermentation and methane emissions. Journal of the Indonesian Tropical Animal $\begin{array}{llll}\text { Agriculture, } & 42(4): & \text { 247-254. }\end{array}$ http://www.doi.org/ 10.14710/jitaa.42.4.247-254

Kim SA, and Rhee MS (2016). Highly enhanced bactericidal effects of medium chain fatty acids (Caprylic, Capric, and Lauric Acid) combined with edible plant essential oils (Carvacrol, Eugenol, $\beta$ Resorcylic Acid, Trans-Cinnamaldehyde, Thymol, and Vanillin) against escherichia coli O15. Food Control, 60: 447-454. DOI: http://www.doi.org/10.1016/j.foodcont.2015.08.022

Krismiyanto L, Nyoman S, and Indrat W (2013). The existence of bacteria and the development of caecum due to the addition of inulin from dahlia bulbs (Dahlia Variabilis) in the combatant village chickens in the starter period. Animal Sciences, 24(3): 54-60. Available at: http://www.jiip.ub.ac.id/

Lenhardt M (2001). "Morphological and functional changes in the small intestine of the newly-weaned pig." Acta Veterinaria Brno, 72: pp. 353-358. Available at: http://www.vfu.cz/acta-vet/actavet.html

Lundin E, Zhang JX, Huang CB, Reuterving CO, Hallmans G, Nygren C, and Stenling R (1993). Oat bran, rye bran, and soybean hull increase goblet cell volume density in the small intestine of the golden hamster a histochemical and stereologic light-microscopic study. Scandinavian Journal of Gastroenterology, 28(1): 15-22. DOI: https://www.doi.org/10.3109/00365529309096039

Marfuah (2016). Cholesterol levels of meat and quality of chicken carcass with the use garlic flour in ration.. Agrisains Journal, 17(3): 116-122. Available http://jurnal.untad.ac.id/jurnal/index.php/AGRISAINS/article/view/ 9954

Mawaddah S, and Hermana W (2018). Effect of deffated larvae BSF (Hermetia Illucens) on production performance of laying quail (Coturnix Coturnix Japonica). Jurnal Ilmu Nutrisi Dan Teknologi Pakan, 16(3): 47-51. DOI: https://www.doi.org/10.29244/jintp

Merkley JW, Weinland BT, Malone GW, and Chaloupka GW (1980). Evaluation of five commercial broiler crosses. Poultry Science, 59(8): 1755-1760. DOI: http://dx.doi.org/10.3382/ps.0591755

Miles RD, Butcher GD, Henry PR, and Littell RC (2006). Effect of antibiotic growth promoters on broiler performance, intestinal growth parameters, and quantitative morphology. Poultry Science, 85(3): 476-485. DOI: http://www/doi.org/ 10.1093/ps/85.3.476

Suartiningsih NPM, Gusti AM, Dewi K, Nuriyasa IM, Wijana IW, Wiyana IKA, and Wirapartha M (2017). Produksi karkas ayam kampung yang diberi ransum kulit buah naga (Hylocereus polyrhizus) terfermentasi. Panduan dan kumpulan Makalah Seminar Nasional VI HITPI, 53(9): 1689-1699. Available at: https://docplayer.info/159049567
Nita N, Dihansih S, and Anggraeni E (2015). Effect of different levels of protein feed against the weight of carcass components and non carcass component of male layer. Jurnal Peternakan Nusantara, 1(2): 89-96. Available at: https://ojs.unida.ac.id/jpnu/article/view/233

Nyoman API, Ketut Berata I, and Made Kardena I (2018). Study of histological development of broiler Chicken jejunum given butyric acid supplements. Indonesia Medicus Veterinus, 7(5): 531-539. DOI: https://www.doi.org/10.19087/imv.2018.7.5.531

Park SIK, Chang BS, and Yoe SM (2014). Detection of antimicrobial substances from larvae of the black soldier fly, Hermetia Illucens (Diptera: Stratiomyidae). Entomological Research, 44(2): 58-64. DOI: https://www.doi.org/10.1111/1748-5967.12050

Pesik HC, Umboh JF, Rahasia CA, and Pontoh CHS (2016). The effect of replacing fish flour with maggot flour (Hermetia Illucens) in broiler rations on the digestibility of calcium and phosphorus. $\begin{array}{llll}\text { Zootec, } & 36(2): & 271-277 . & \text { DOI: }\end{array}$ https://doi.org/10.35792/zot.36.2.2016.11499

Philip (1993). Development of lactic acid bacteria as health food supplement or probiotics. OMX International. Malaysia, pp. 435454 .

Purnamawati Y (2015). Performance of broiler chicken with hongkong caterpillar flour (Tenebrio Molitor L.) as a substitute for meat and bone meal. essay. Nutrition and Feed Technology. IPB University Scientific Repository. Available at: http://repository.ipb.ac.id/handle/123456789/88340

Rahmanto (2012). Small intestine histology structure and feed efficiency of free-range chickens and broiler chickens. Educational Research, 7(2): $\quad 40-60 . \quad$ DOI: http://www.doi.org/10.21831/eprint.uny.ac.id/id/eprint/8396

Rahmawati (2016). Histologis saluran pencernaan ayam buras hasil in ovo feeding asam amino. Thesis. Produksi Ternak. Universitas Hasanuddin, pp. 45-51. Available at: http://repository.unhas.ac.id/bitstream/handle/123456789

Satimah S, Yunianto VD, and Wahyono F (2019). Relative weight and length of small intestines of broiler chickens rationed using microparticle eggshells with probiotic lactobacillus Spp. Journal of Indonesian Animal Science, 14(4): 396-403. DOI: https://www.doi.org/10.31186/jspi.id.14.4.396-403

Savory CT, and Gentle MJ (1976). Changes in food intake and gut size in japanese quail in response to manipula-tion of dietary fibre content. British Poultry Science, 17(6): 571-580. DOI: http://www.doi.org/10.1080/00071667608416315

Soeparno (2009). Ilmu dan teknologi daging. Gadjah Mada University Press, Yogyakarta, pp. 346. Available at: https://ugmpress.ugm.ac.id/id/product/peternakan/ilmu-danteknologi-daging

Spranghers T, Ottoboni M, Klootwijk C, Ovyn A, Deboosere S, De Meulenaer B, Michiels J, Eeckhout M, De Clercq P, and De Smet S (2017). Nutritional composition of black soldier fly (Hermetia illucens) prepupae reared on different organic waste substrates. Animal Feed Science and Technology, 97(8): 2594-2600. DOI: http://www.dx.doi.org/ 10.1002/jsfa.8081

Steel RGD, and Torrie JH (1980). Principles and procedures of statistics (Biometric Approach). 2nd Edition. MCGraw-Hill Company, New York, pp. 20-90. DOI: https://doi.org/10.1002/bimj.19620040313

Suprijatna E, Atmomarsono U, and Kartasudjana R (2008). Ilmu dasar ternak unggas. Penebar Swadaya. Jakarta, pp. 175-207. Available at: https://www.unpad.ac.id/buku/ilmu-dasar-ternak-unggas/

Swatland HJ (1984). Structure and development of meat animal. prenticed hall inc. Englewood cliffs, New Jersey. Canadian Institute of Food Science and Technology journal, pp. 436-460. DOI: http://www.doi.org/10.1016/S0315-5463(85)71707-5

Tang Z, Yin Y, Zhang Y, Huang R, Sun Z, Li T, Chu W, Kong X, Li L, Geng $M$ et al. (2009). Effects of dietary supplementation with an 
expressed fusion peptide bovine lactoferricin-lactoferrampin on performance, immune function and intestinal mucosal morphology in piglets weaned at age 21 D." British Journal of Nutrition, 101(7): 998-1005. DOI: https://www.doi.org/10.1017/S0007114508055633

Wang Y, Shan T, Xu Z, Liu J, and Feng J (2006). Effect of lactoferrin on the growth performance, intestinal morphology, and expression of PR-39 and protegrin-1 genes in weaned piglets. Journal of Animal Science, $\quad$ 84(10): 2636-2641. DOI: http://www.doi.org/10.2527/jas.2005-544

Willems O.W, S.P Miller and B.J.Wood (2013). Aspect of selection for feed efficiency in meet producing poultry. World's Poultry Science Journal, $69(1)$ : $77-88$. https://www.doi.org/10.1017/S004393391300007X

Yamauchi KE, and Isshiki Y (1991). Scanning electron microscopic observations on the intestinal villi in growing white leghorn and broiler chickens from 1 to 30 days of age. British Poultry Science, 32(1): $\quad 67-78$. http://www.doi.org/10.1080/00071669108417328

Zainuddin, Dian M, Sarayulis, and Jalaluddin M (2016). Histology of intestinal glands in the duodenum of kampung chickens (Gallus Domesticus), doves (Columba Domesticus) and ducks (Anser Anser Domesticus). Medika Veterinaria, 10(1): 9-11. DOI: http://www.doi.org/10.21157/j.med.vet..v10i1.4028

Zhou F, Tomberlin KJ, Zheng L, Yu Z, and Zhang J (2013). Developmental and waste reduction plasticity of three black soldier fly strains (Diptera: Stratiomyidae) raised on different livestock manures. Journal of Medical Entomology, 50(6): 1224-1230. DOI: http://www.doi.org/10.1603/ME13021 